\title{
LIPOLYTIC ACTIVITY OF SOME DERMATOPHYTES
}

\author{
L. HeLlgRen AND J. VinCENT \\ Department of Dermatology, University of Trondheim, Trondheim, Norway,
}

THE HORNY layer of epidermis, which can be colonised by dermatophytes, is covered by surface lipids. The lipolytic activity of dermatophytes may therefore be of particular importance in the early stages of infection, before the fungus has established permanent contact with keratin; but little is known about the possible presence of lipases in these pathogenic fungi. The early observations of Mallinckrodt-Haupt (1927), Tate (1929), Nékám (1935) and, more recently, Pinetti and Lostia (1961) and Böhme (1969) have demonstrated that dermatophytes can hydrolyse lipids of animal and of vegetable origin. The occurrence of lipase has been demonstrated histochemically (Knight, 1957) and in dermatophyte mycelial filtrates (Böhme, 1969). This paper describes the screening of the more common dermatophytes to test for the presence of lipases.

\section{Material AND MethodS}

Dermatophyte strains. Nine strains each of Epidermophyton floccosum, Microsporum canis, Trichophyton mentagrophytes and T. rubrum were isolated from patients and were propagated from single spores (Dinh-Nguyen and Vincent, 1972).

Substrate. A culture medium with low dextrose content (Ullmann and Blasius, 1974) was supplemented with tributyrin $0 \cdot 1 \%(\mathrm{w} / \mathrm{v})$, as a main carbon source. In pilot studies, the range of lipolytic activity of dermatophytes was studied on media supplemented with $0.1 \%$ of one of the following lipids: olive oil, peanut oil, Tween 20 , Tween 40, Tween 60 and Tween 80 .

Experimental procedure. A standard mycelial suspension (Vincent, 1972) from an approximately 10-day-old culture was used as inoculum. A lipid was dispersed in the substrate by homogenisation (Ultra-Turrax). The extent of the lipolytic activity in tributyrin-supplemented media was indicated by the size of a clear zone around the colony and in media supplemented with other lipids by an opaque zone. The sizes of the zones were compared and a ranking scale was applied to measure the relation between them; they were recorded, in decreasing order, as ,+++++ , and + (Siegel, 1956), with intermediate values in parenthesis. The results were read after 3-10 days depending on the strain tested. All tests were done in triplicate.

Statistical method. The Kendall coefficient of concordance (Kendall, 1948) was used to indicate the differences between the ranks. A high rank sum indicates poor lipolytic activity.

\section{RESULTS}

In the pilot trials the dermatophytes hydrolysed, in descending order of activity, olive oil, peanut oil, Tween 60 , and Tween 80; Tweens 20 and 40 were rarely split. In the tributyrin medium there was considerable variation in the lipolytic activity of different dermatophytes and between different strains of the same species (table). The lipolytic activity of $M$. canis was comparatively high, while $T$. mentagrophytes and $E$. floccosum had moderate lipolytic activities. T. rubrum seemed to lack lipolytic enzymes.

Received 9 Mar. 1979; revised version accepted 3 June 1979.

Correspondence and requests for reprints should be sent to Dr J. Vincent, Department of Dermatology, University of Trondheim, Trondheim, Norway. 
TABLE

Comparison of the lipolytic zones around strains of dermatophytes grown on tributyrin agar

\begin{tabular}{|c|c|c|c|c|}
\hline \multirow[b]{2}{*}{ Strain no. } & \multicolumn{4}{|c|}{$\begin{array}{l}\text { Ranking* of sizes of lipolytic zones } \\
\text { a round colonies of }\end{array}$} \\
\hline & $\begin{array}{l}\text { Epidermophyton } \\
\text { floccosum }\end{array}$ & $\begin{array}{l}\text { Microsporum } \\
\quad \text { canis }\end{array}$ & $\begin{array}{l}\text { Trichophyton } \\
\text { mentagrophytes }\end{array}$ & $\begin{array}{l}\text { Trichophyton } \\
\text { rubrum }\end{array}$ \\
\hline $\begin{array}{l}1 \\
2 \\
3 \\
4 \\
5 \\
6 \\
7 \\
8 \\
9\end{array}$ & $\begin{array}{l}+(+) \\
++ \\
+ \\
++(+) \\
++ \\
++ \\
+(+) \\
++ \\
++\end{array}$ & $\begin{array}{l}+++ \\
+++ \\
+++(+) \\
+++ \\
++(+) \\
+++ \\
+++ \\
++ \\
+++\end{array}$ & $\begin{array}{l}++(+) \\
++(+) \\
+++ \\
++ \\
++(+) \\
++ \\
++ \\
++ \\
+++\end{array}$ & $\begin{array}{l}(+) \\
- \\
- \\
- \\
+ \\
- \\
- \\
- \\
-\end{array}$ \\
\hline $\begin{array}{l}\text { Coefficient of } \\
\text { concordance } \\
\text { (rank sum) } \dagger\end{array}$ & $24 \cdot 5 \ddagger$ & $11 \cdot 0 \ddagger$ & $18 \cdot 5 \ddagger$ & $36 \cdot 0 \ddagger$ \\
\hline
\end{tabular}

* Siegel (1956); intermediate values are shown in parenthesis.

$\dagger$ Kendall (1948).

$\pm \mathrm{p}<0 \cdot 05$.

\section{DisCUSSION}

That different strains of dermatophytes showed a significant difference in their lipolytic activity may be clinically important. Thus $T$. rubrum, in which lipolytic activity was not detected, may penetrate with difficulty the mammalian skin which is covered with a comparatively thick layer of lipids. This could explain why T. rubrum is often localised to the palms of the hands and soles of the feet, which lack sebaceous glands. In the laboratory, the absence of lipolytic activity in $T$. rubrum seems to be a convenient way of distinguishing it from $T$. mentagrophytes (Böhme, 1969), particularly if the strains are atypical in other properties.

Different strains of the same dermatophyte show differences in their lipolytic activity. The substrate specificity of lipolysis is however generally low; our pilot studies on a range of lipids suggest the existence of a broad-spectrum lipase in dermatophytes but this possibility was not tested directly.

The lipase of dermatophytes could be of vital importance for their parasitic existence, if they can use lipids as a primary carbon source, before they penetrate to the lower, more protein-rich layers of epidermis. However, the human skin-surface lipids contain a large fraction of fatty acids; these originate from the bacterial hydrolysis of triglycerides and some of them, particularly those with a molecular weight around that of undecylenic acid, have fungistatic properties and are useful in therapy of dermatophyte infections. The discrepancy between on the one hand the inhibitory effect of the fatty acids present in the skin-surface lipids and on the other the possibility that skin lipids can promote fungal growth can be explained by the autoregulatory mechanism of the fungal lipolysis. The activity of the fungal lipase is inversely related to the amount of fatty acids released because the fungal lipases are inactivated by excess of fatty acids.

Further investigations are now in progress on the lipolytic activity of $E$. floccosum.

\section{SUMMARY}

The lipolytic activities of four common dermatophytes, Epidermophyton floccosum, Microsporum canis, Trichophyton mentagrophytes and T. rubrum, were tested on agar medium supplemented with one or other of several lipids. The lipolytic activity was estimated by comparison 
of the zone sizes around the colonies. The highest lipolytic activity was demonstrated by $M$. canis, followed by $T$. mentagrophytes and $E$. floccosum; $T$. rubrum virtually lacked lipolytic activity. The clinical importance of these observations and their application in the identification of dermatophytes is discussed.

\section{REFERENCES}

BöнмE, H. 1969. Vergleichende Untersuchungen an Dermatophyten und anderen keratinophilen Pilzen über Wachstum, Stoffwechsel und Enzymausscheidung mit Lipiden als Hauptkohlenstoffquellen. Thesis, Halle/Saale.

DiNH-NGUYEN, NG, AND VINCENT, J. 1972. A simple monospore selector. Mykosen, 15, 343.

Kendall, M. G. 1948. Rank correlation methods. Griffin: London.

KNIGHT, S. G. 1957. The mechanism of triglyceride therapy in dermatomycoses. J. invest. Derm., 28, 363.

MallinCKrodt-Haupt, A. von 1927. Der Fettstoffwechsel der Hautpilze. Das Fettspaltungsvermögen der lebenden Pilzkultur. Zentbl. Bakt. ParasitKde, I. Abt. Orig., 103, 73.

NéKÁM, L. JR. 1935. Über den quantitativen Fermentgehalt der Parasitären und Hautpathogenen Pilze. Z. ParasitKde, $8,121$.

PinetTi, P. AND Lostia, A. 1961. Contributo allo studio delle lipasi dermatomicetiche. Rass. med. Śarda, 63, 355.

SIEGEL, S. 1956. Nonparametric statistics for the behavioral sciences. McGraw-Hill: New York, Toronto, London.

TATE, P. 1929. On the enzymes of certain dermatophytes or ringworm fungi. Parasitology, 21, 31.

UllmanN, U. and Blasius, C. 1974. Ein modifiziertes, einfaches Verfahren zur Bestimmung der unterschiedlichen lipolytischen Aktivitäten von Mikroorganismen. Zentbl. Bakt. ParasitKde, I. Abt. Orig., A229, 264.

VINCENT, J. 1972. Mycelial suspensions prepared ultrasonically. Experientia, 28, 722. 